\title{
Leaf rolling reduces photosynthetic loss in maize under severe drought
}

\author{
Aykut Saglam $^{1 *}$, Asim Kadioglu ${ }^{2}$, Mehmet Demiralay $^{2,3}$, Rabiye Terzi $^{2}$ \\ ${ }^{1}$ Karadeniz Technical University, Faculty of Science, Molecular Biology and Genetics, \\ 61080 Trabzon, Turkey \\ ${ }^{2}$ Karadeniz Technical University, Faculty of Science, Biology, 61080 Trabzon, Turkey \\ ${ }^{3}$ Artvin Çoruh University, Faculty of Sciences and Letters, Biology, 08000, Artvin, Turkey
}

\begin{abstract}
Effects of leaf rolling (LR) on maize photosynthesis under severe drought stress were studied in two cultivars with opposite drought responses, Batem 56-55 (drought tolerant) and Batem 51-52 (drought sensitive). Drought stress and artificial prevention of leaf rolling (PLR) were applied at grain filling stage for 30 days. LR in Batem 56-55 occurred later than in Batem 51-52. Leaf water potential $\left(\Psi_{\text {leaf }}\right)$ did not change in Batem 56-55 but decreased in Batem 51-52 at LR. Maximum quantum yield of photosystem II $\left(\mathrm{F}_{\mathrm{v}} / \mathrm{F}_{\mathrm{m}}\right)$, effective quantum yield of photosystem II $\left(\Phi_{\mathrm{PSII}}\right)$ and electron transport rate (ETR) of the cultivars decreased during LR more significantly in Batem 56-55 in comparison to Batem 51-52. The same was observed for the decrease in net photosynthetic rate $\left(\mathrm{P}_{\mathrm{N}}\right)$, stomatal conductance $\left(\mathrm{g}_{\mathrm{s}}\right)$, transpiration $(\mathrm{E})$ and intracellular level of $\mathrm{CO}_{2}\left(\mathrm{C}_{\mathrm{j}}\right)$. Rubisco activity and content were reduced at LR, but were less affected in Batem 56-55 than in Batem 51-52. Ear and kernel weights also decreased at LR. All parameters at PLR were more reduced than those of LR. These results implied that LR was an important and necessary mechanism protecting photosynthesis and reducing yield loss under drought stress by maintaining the leaf hydration, preventing loss of the photosynthetic pigments, sustaining the activity of PSII, keeping the stomata open, and conserving the activity of Rubisco.
\end{abstract}

Keywords: drought, leaf rolling, maize, photosynthesis, yield

Abbreviations: $\mathrm{Car}$ - carotenoid, $\mathrm{Chl}-$ chlorophyll, $\mathrm{C}_{\mathrm{i}}-$ intracellular $\mathrm{CO}_{2}$, dw - dry weight, $\mathrm{E}$ - transpiration, ETR - electron transport rate, $\mathrm{F}_{\mathrm{v}} / \mathrm{F}_{\mathrm{m}}$ - maximum quantum yield of PSII, $\Phi_{\text {PSII }}$ - effective quantum yield of PSII photochemistry, $g_{\mathrm{s}}-$ stomatal conductance, $\mathrm{LR}$ - leaf rolling, NPQ - nonphotochemical quenching, $\mathrm{P}_{\mathrm{N}}-$ net photosynthetic rate, PSII - photosystem II, PLR - prevention of leaf rolling, $\Psi_{\text {leaf }}$ - leaf water potential

\section{Introduction}

Maize is one of the key sources of human nutrition and is becoming an increasingly valuable crop due to the decrease in rice production and an enhanced demand for meat products

*Corresponding author, e-mail: aykut_saglam@yahoo.com 
and dairy (SALVI et al. 2007). Maize is grown mostly under rain-fed conditions and is more susceptible to drought than other cereals. In addition drought is unpredictable. Therefore drought tolerance is an important factor in maize breeding (BANZIGER and ARAUS 2007). Grain yield is reduced by drought but depends on plant species, developmental stages, variety of the plants, and intensity of the stress (Grzesiak et al. 2013). Maize is especially vulnerable to soil drought during grain-filling periods (BAI et al. 2006). The decrease of grain yield in maize under drought stress has been the subject of recent studies. For instance, a five-day drought stress during pollination has caused formation of aborted embryos and decrease in kernel numbers in maize (ZinselmeIER et al. 1999). Drought stress and shading during pre and post pollination stages have decreased kernel set in the apical regions of maize ears (SETTER et al. 2001).

The photosynthetic process is impaired mostly by drought stress (CHAVEs et al. 2009) due to both stomatal and non-stomatal limitations, which lead to a decrease in photosynthetic activity (ZLATEV and Yordanov 2004). Stomatal closure is one of the earliest responses of the plants to drought, reducing transpiration, $\mathrm{CO}_{2}$ uptake and photosynthetic activity (DE SouZA et al. 2013). The limitation of $\mathrm{CO}_{2}$ uptake causes an imbalance between PSII activity and the Calvin cycle, increasing the excitation energy on PSII, and subsequent photodamage (BAKER and RosenQvist 2004), mainly to the PSII oxygen-evolving complex, and the disruption of D1 protein, resulting in inactivation of PSII reaction centers (ASHRAF and HARRIS 2013).

A number of mechanisms are involved in plant defense strategies against drought stress such as reduction of leaf size, leaf movement or leaf rolling (LR) (KADIOGLU et al. 2012). Although, there are many studies about the effects of drought on photosynthesis in plants, there are still few studies showing changes in photosynthesis during LR under drought stress. For example, a relation between LR and susceptibility to photoinhibition of sorghum photosynthesis under drought was reported (CORLETT et al. 1994). In Ctenanthe setosa, LR was reported to protect PSII against damage under severe drought (NAR et al. 2009). Furthermore, moderate LR increased efficiency of photosynthesis in rice (LANG et al. 2004). However, the effects of LR on photosynthetic yield regarding agronomic parameters and cultivars have not been studied. Thus, in the present study, the effects of LR on photosynthesis yield and drought-response mechanisms are elucidated. We hypothesized that LR could protect photosynthesis from drought stress and preserve maize yield. In addition, delayed or late LR has been associated with drought tolerance in rice cultivars (SINGH and MAcKILL 1990). On the other hand, how delayed LR affects photosynthesis and yield has not yet been fully elucidated. Therefore, the effects of artificial prevention of leaf rolling (PLR) on photosynthesis under drought stress was investigated as well as the way in which LR affects photosynthesis in cultivars with contrasting drought tolerance.

\section{Material and methods}

\section{Growth of the plants and stress treatments}

The experiment was carried out between May and August 2008, 2009 and 2010 at

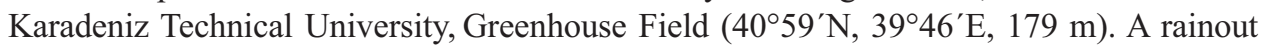
shelter ( $8 \mathrm{~m}$ width $\times 15 \mathrm{~m}$ length $\times 3 \mathrm{~m}$ height $)$ was constructed as a tunnel open at both ends and kept $150 \mathrm{~cm}$ above ground to allow free airflow and avoid rises in temperature due to 
the greenhouse effect on an open field and covered with polyethylene transmitting more than $90 \%$ of sunlight. The plants were grown in the rainout shelter under sunlight. Average temperature of the field was 21.8 $\pm 4.1^{\circ} \mathrm{C}$ between May and August in 2008-2010. Seeds of the maize cultivars (Batem 51-52 and Batem 56-55) were obtained from Western Mediterranean Agricultural Research Institute, Antalya, Turkey; Batem 51-52 was reported as drought sensitive and Batem 56-55 as drought tolerant (SARUHAN et al. 2012). Cultivars were determined as drought tolerant/sensitive based on their leaf water potentials, stomatal conductance, proline and malondialdehyde (MDA) contents after 30 days of drought stress, to which the plants were exposed at grain filling stage (R2). Eight seeds were sown in pots (30 $\mathrm{cm}$ diameter and $50 \mathrm{~cm}$ deep) filled to $47.5 \mathrm{~cm}$ height with $14 \mathrm{~kg}$ of fully water-saturated sandy soil. There were twelve pots for each cultivar. After full germination, seedlings were reduced to two in each pot. Plants were kept well irrigated and grown to stage R2 by adding one and half liters of water to each pot every other day. At stage R2, half of the plants were kept well watered (control), while the others were subjected to drought stress by withholding water for 30 days until maturity was reached. To investigate the effect of LR on photosynthesis during drought, LR was artificially inhibited (PLR) by clamping leaves with plastic wires in the beginning of drought application. Leaves ( $6^{\text {th }}$ leaf from top) were harvested on the $30^{\text {th }}$ day of drought. Leaf rolling degree, water status and temperature were measured, in addition to photosynthetic pigment content, chlorophyll $a$ fluorescence, photosynthetic gas exchange parameters, Rubisco activity, Rubisco content and some agronomic characteristics.

\section{Leaf rolling degree and water status}

Leaf rolling degree was measured according to PREMACHANDRA et al. (1993) as a percentage reduction in the width of the leaf mid-portion. Leaf water potential $\left(\Psi_{\text {leaf }}\right)$ was measured with a thermocouple psychrometer (C-52, Wescor) after it had been calibrated by using $\mathrm{NaCl}$ solutions of known water potentials. Discs about $6 \mathrm{~mm}$ in diameter were cut from the leaves of three plants and sealed in the C-52 sample chamber. Samples were equilibrated for $60 \mathrm{~min}$ before the readings were recorded by a water-potential data logger (PSYPRO, Wescor Inc., Logan, UT USA) in the psychrometric mode.

\section{Lipid peroxidation}

Lipid peroxidation was measured in terms of malondialdehyde (MDA) content $(\varepsilon=155$ $\mathrm{mM}^{-1} \mathrm{~cm}^{-1}$ ), a product of lipid peroxidation following the method of HEATH and PACKER (1968). Leaf samples $(0.5 \mathrm{~g})$ were homogenized in $10 \mathrm{ml}$ of $0.1 \%(\mathrm{w} / \mathrm{v})$ trichloroacetic acid (TCA). As much as $4 \mathrm{ml}$ of $0.5 \%(\mathrm{w} / \mathrm{v})$ thiobarbituric acid containing $20 \%(\mathrm{w} / \mathrm{v})$ of TCA was added to $1 \mathrm{ml}$ aliquot of supernatant. The absorbance of the supernatant was recorded at 532 and $600 \mathrm{~nm}$ and MDA content was expressed as nmol MDA per $\mathrm{g}$ fresh weight (nmol $\left.\mathrm{MDA} \mathrm{g}^{-1} \mathrm{fw}\right)$.

\section{Photosynthetic pigments}

Total chlorophyll (Chl) and carotenoid (Car) contents were determined following the method of ARNON (1949). The $6^{\text {th }}$ leaf from the tops of different plants of the same age were selected randomly and homogenized in a mortar in $80 \%$ acetone. The extract was centri- 
fuged at 5,000 g for $5 \mathrm{~min}$. Absorbance of the supernatant was recorded at 663, 645, and 450 $\mathrm{nm}$ by spectrophotometer (Nicolet evolution 100, Thermo Scientific, USA). Content was expressed as $\mathrm{mg}$ of pigments per $\mathrm{g}$ dry weight $\left(\mathrm{mg} \mathrm{g}^{-1} \mathrm{dw}\right)$.

\section{Thermal imaging}

Thermal images were obtained using a Thermovision A20 infrared camera (FLIR Systems, USA) according to VoLLSNES et al. (2009). The infrared camera was mounted vertically $\sim 10 \mathrm{~cm}$ above the leaf. Each leaf was positioned in the camera view field to focus the image and to maximize the image area covered by the leaf. The images of the $6^{\text {th }}$ leaf from the tops of six different plants were captured. Images were analyzed for temperature determination using the ThermaCAM Researcher software (LiU et al. 2011).

\section{Chlorophyll a fluorescence measurements}

Chlorophyll $a$ fluorescence measurements were performed by pulse modulated fluorometer (OS1-FL, OptiScience Corporation, Tyngsboro, MA, USA) according to NAR et al. (2009) between 10:00 and 14:00 $\mathrm{h}$ at the grain-filling stage in the rainout shelter under sunlight. For each treatment, the $6^{\text {th }}$ leaf from six different plants was selected and clamped at the center point with the OS1-FL leaf clip holder. Leaves were dark-adapted for 20 min and the $\mathrm{Chl}$ fluorescence was then measured. Minimum $\mathrm{Chl}$ fluorescence yield $\left(\mathrm{F}_{0}\right)$ was deter-

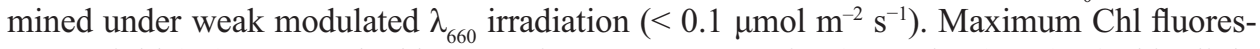
cence yield $\left(\mathrm{F}_{\mathrm{m}}\right)$ was reached by exposing PSII to saturating $\lambda_{690}$ pulse $(0.8 \mathrm{~s})$ of white light $\left(8,000 \mu \mathrm{mol} \mathrm{m} \mathrm{m}^{-2} \mathrm{~s}^{-1}\right)$. After dark measurements, the leaves were exposed to the red actinic light of the fluorometer together with the sunlight functioning as actinic light source. Steady state $\mathrm{Chl}$ fluorescence $\left(\mathrm{F}_{\mathrm{s}}\right)$ was achieved after exposure to the actinic light. A simultaneous saturating pulse $(0.8 \mathrm{~s})$ of white light $\left(8,000 \mu \mathrm{mol} \mathrm{m} \mathrm{m}^{-2} \mathrm{~s}^{-1}\right)$ was applied to determine maximum $\mathrm{Chl}$ fluorescence in the light $\left(\mathrm{F}_{\mathrm{m}}{ }^{\prime}\right)$. Maximum quantum yield of PSII photochemistry $\left(\mathrm{F}_{\mathrm{v}} / \mathrm{F}_{\mathrm{m}}\right)$ and effective quantum yield of PSII photochemistry $\left(\Phi_{\mathrm{PSII}}\right)$ were calculated according to the following equations $\left(\mathrm{F}_{\mathrm{v}} / \mathrm{F}_{\mathrm{m}}=\left(\mathrm{F}_{\mathrm{m}}-\mathrm{F}_{0}\right) / \mathrm{F}_{\mathrm{m}}\right.$ and $\left.\Phi_{\mathrm{PSII}}=\left(\mathrm{F}_{\mathrm{m}}{ }-\mathrm{F}_{\mathrm{s}}\right) / \mathrm{F}_{\mathrm{m}}{ }^{\prime}\right)$ of GENTY et al. (1989). Nonphotochemical quenching (NPQ) was calculated according to the equation, $\mathrm{NPQ}=\left(\mathrm{F}_{\mathrm{m}}-\mathrm{F}_{\mathrm{m}}{ }^{\prime}\right) / \mathrm{F}_{\mathrm{m}}$ '. Electron transport rate $(\mathrm{ETR})$ was calculated according to following equation, $\mathrm{ETR}=\left(\Phi_{\mathrm{PSII}} \times \mathrm{PAR} \times 0.5 \times 0.84\right)$. PAR was measured with a PAR clip. Value 0.5 indicates partitioning of energy between PSII and PSI, while value 0.84 presents proportional light absorbance by photosynthetic tissue.

\section{Photosynthetic gas exchange measurements}

Stomatal conductance $\left(\mathrm{g}_{\mathrm{s}}\right)$ was monitored on the $6^{\text {th }}$ leaf from six different plants by using a dynamic diffusion porometer (AP4, Delta-T Devices, Burwell, Cambridge, UK) after it had been calibrated with a standard calibration plate following the manufacturer's instructions. Other gas exchange parameters were measured using a portable photosynthesis system (TPS-2 Photosynthesis System, PP Systems, Amesbury, MA, USA) equipped with a 25 $\times 18 \mathrm{~mm}$ PLC6 automatic universal leaf cuvette on the $6^{\text {th }}$ leaf from six different plants under natural sunlight. Middle parts of the selected leaves were measured from 10:00 to 14:00 h. The parameters measured were transpiration $(\mathrm{E})$, net photosynthetic rate $\left(\mathrm{P}_{\mathrm{N}}\right)$ and intracellular $\mathrm{CO}_{2}\left(\mathrm{C}_{\mathrm{i}}\right)$. 


\section{Agronomic characteristics}

Grain yield and yield components were evaluated through ear weight and 100-kernel weight in six plants.

\section{Determination of Rubisco activity}

About $0.25 \mathrm{~g}$ of frozen maize leaves were ground to a powder using a chilled mortar and pestle with liquid $\mathrm{N}_{2}$, a small amount of quartz sand, and insoluble polyvinylpolypyrrolidone (PVP). Tissues were homogenized with cooled extraction buffer containing $50 \mathrm{mM}$ of Tris- $\mathrm{HCl}$ (pH 7.5), $1 \mathrm{mM}$ of ethylenediaminetetraacetic acid (EDTA), $10 \mathrm{mM}$ of $\mathrm{MgCl}_{2}$, $12 \%(\mathrm{v} / \mathrm{v})$ of glycerol, $0.1 \%(\mathrm{v} / \mathrm{v})$ of $\beta$-mercaptoethanol and $1 \%(\mathrm{w} / \mathrm{v})$ of PVP-40 (soluble PVP) at $0-4{ }^{\circ} \mathrm{C}$. The homogenate was centrifuged at $15,000 \mathrm{~g}$ for $15 \mathrm{~min}$ at $4{ }^{\circ} \mathrm{C}$. Protein contents of the homogenates were determined as described by BRADFORD (1976) using bovine serum albumin as a standard. The Rubisco activity in the supernatant was assayed according to SAWADA et al. (2003) with minor modifications. The Rubisco activity was measured at $30{ }^{\circ} \mathrm{C}$ for 10 minutes by adding $100 \mu \mathrm{l}$ of supernatant into $900 \mu \mathrm{l}$ of assay buffer containing $50 \mathrm{mM}$ of HEPES-KOH (pH 8.0), $1 \mathrm{mM}$ of EDTA, $20 \mathrm{mM}$ of $\mathrm{MgCl}_{2}, 25 \mathrm{mM}$ of dithioerythritol, $10 \mathrm{mM}$ of $\mathrm{NaHCO}_{3}, 5 \mathrm{mM}$ of ATP, $0.15 \mathrm{mM}$ of nicotinamide adenine dinucleotide (NADH), $5 \mathrm{mM}$ of creatine phosphate, $0.6 \mathrm{mM}$ of ribulose-1,5-bisphosphate (RuBP), 10 units of phosphocreatine kinase, 10 units of glyceraldehyde-3-phosphate dehydrogenase and 10 units of phosphoglycerate kinase. Total Rubisco activity was expressed in units per milligram protein.

\section{Determination of Rubisco content}

To determine Rubisco content, leaves were homogenized as described in the Rubisco activity assay. Sodium dodecyl sulfate polyacrylamide gel electrophoresis (SDS-PAGE) of leaf protein was carried out in a vertical slab gel discontinuous buffer system following the method of LAEMmLi (1970) using a 7\% acrylamide gel concentration. A total volume of 20 $\mu \mathrm{l}$ protein extract solution including $30 \mu \mathrm{g}$ of total protein was loaded into each well. In addition, to quantify the amount of Rubisco in the leaf homogenates, Rubisco recombinant protein standards ranging from 0.0625 to 0.25 pmol were also loaded. Protein molecular mass standard (Thermo Fisher Scientific, Waltham, MA) was used. The gels were run at approximately $80 \mathrm{~mA}$ for $30-40 \mathrm{~min}$ in electrophoresis buffer by using a Mini-PROTEAN Tetra Cell electrophoretic unit (Biorad, Germany). Proteins were then transferred to polyvinylidene fluoride (PVDF) transfer membrane (Whatman, Dassel, Germany) in McFarland's electroeluting buffer (12 mM Tris base, $96 \mathrm{mM}$ glycine, and 20\%, v/v, methanol) at $<25 \mathrm{~V}$ for $45 \mathrm{~min}$. The blotted membrane was subjected to immunodetection of Rubisco according to MA et al. (2009). The PVDF blot was placed in $10 \mathrm{ml}$ of blocking solution (TBST; 5\%, $\mathrm{w} / \mathrm{v}$, nonfat dry milk in $24.8 \mathrm{mM}$ Tris, $\mathrm{pH} 7.4,150 \mathrm{mM} \mathrm{NaCl}, 2.7 \mathrm{mM} \mathrm{KCl}$, and $0.5 \%$, v/v, Tween 20) and rocked gently on a rotary shaker or platform rocker for $30 \mathrm{~min}$ then washed four times for $5 \mathrm{~min}$ each with TBST and incubated for $1 \mathrm{~h}$ on a shaker-rocker with polyclonal rabbit anti-rubisco antibody (anti-rubisco large subunit global antibody, diluted 1:6,000; Agrisera, Vännäs, Sweden). After four 2.5-min washes with TBST, the blot was incubated with goat anti-rabbit immunoglobulin $\mathrm{G}(\mathrm{IgG})$ polyclonal antibody conjugated to horseradish peroxidase (diluted 1:2,000; Agrisera, Vännäs, Sweden) for 30 min on the shaker. After four 2.5-min washes, chromogenic substrate solution for horseradish peroxidase 
$(0.015 \%, \mathrm{w} / \mathrm{v}$, of 4-chloro-1-napthol and $0.05 \%, \mathrm{v} / \mathrm{v}$, hydrogen peroxide in TBS containing $16.7 \%$, v/v methanol) was added, and the blot was allowed to develop $15 \mathrm{~min}$. The blot was then rinsed three times in water for $2 \mathrm{~min}$ each. The developed blot was allowed to dry on a clean piece of filter paper and stored in a ziplock bag at $-20^{\circ} \mathrm{C}$. The Western blot image of protein bands was captured with a scanner (HP Scanjet 4850; Hewlett Packard, Palo Alto, CA). A comparison of the average intensity of each band from western blot analysis was quantified with the use of the ImageJ analysis program (ImageJ 1.34s; http://rsbweb.nih. gov/ij/).

\section{Statistical analysis}

Each measurement was conducted three times with six biological replicates. Variance analysis of mean values was performed with Duncan Multiple Comparison test (two-way ANOVA) using SPSS software for Microsoft Windows (Ver. 13.0, SPSS Inc., USA) and significance was determined at $\mathrm{P}<0.05$ level.

\section{Results}

\section{Leaf rolling degree and water status}

Leaves of Batem 56-55, drought tolerant cultivar, rolled two days later than Batem 5152 , drought sensitive cultivar, under drought. In addition, LR degree (\%) in Batem 51-52 $(77.0 \pm 0.5)$ was higher than Batem 56-55 (65.0 \pm 2.7$)$.

The leaf water potential $\left(\Psi_{\text {leaf }}\right)$ control values were $-0.30 \pm 0.01$ and $-0.50 \pm 0.03 \mathrm{MPa}$ in control groups of Batem 51-52 and Batem 56-55, respectively. The $\Psi_{\text {leaf }}$ significantly decreased (6-fold) in Batem 51-52 at LR (-1.81 $\pm 0.03 \mathrm{MPa})$ compared to the control (Fig. 1). However, the $\Psi_{\text {leaf }}$ did not change in Batem 56-55 (-0.51 $\left.\pm 0.02 \mathrm{MPa}\right)$. At PLR, decreases in $\Psi_{\text {leaf }}$ were measured in both Batem 51-52 $(-2.30 \pm 0.02 \mathrm{MPa})$ and Batem 56-55 $(-1.20 \pm$ $0.03 \mathrm{MPa}$ ) compared to the controls (Fig. 1). $\Psi_{\text {leaf }}$ in Batem 56-55 at PLR was 7.8 fold lower than its control, while $\Psi_{\text {leaf }}$ in Batem 51-52 was 2.4 fold lower than its control.

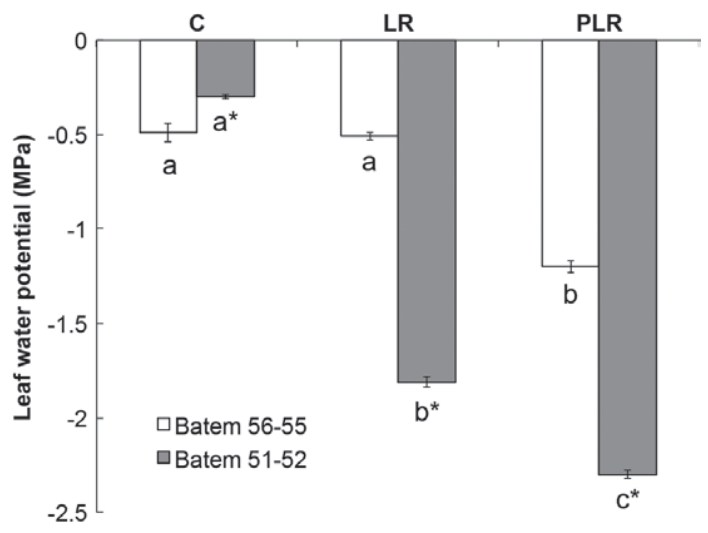

Fig. 1. Changes in leaf water potential of maize cultivars. C - control, LR - leaf rolling, PLR - prevention of leaf rolling. Different small letters show statistical differences at $\mathrm{P}<0.05$ among $\mathrm{C}, \mathrm{LR}$ and PLR of same cultivar. Asterisk denotes significant differences between cultivars. Vertical bars are standard deviation of means. 


\section{Photosynthetic pigments}

The total Chl content in Batem 51-52 decreased from $5.20 \pm 0.01 \mathrm{mg} \mathrm{g}^{-1} \mathrm{dw}$ (control) to $1.50 \pm 0.01 \mathrm{mg} \mathrm{g}^{-1} \mathrm{dw}$ at LR (Fig. 2A) while the total Chl content increased from $5.9 \pm 0.03$ $\mathrm{mg} \mathrm{g}^{-1} \mathrm{dw}$ (control) to $6.50 \pm 0.01 \mathrm{mg} \mathrm{g}^{-1} \mathrm{dw}$ in Batem 56-55 at LR. Total Chl content in Batem 51-52 was 3.5 fold lower at LR than in the control. On the other hand, the Chl content in Batem 56-55 was 1.1 fold higher at LR than in the control. In addition, the total Chl content at PLR was also lower than that of the control. The Chl content in Batem 51-52 was $1.00 \pm 0.01 \mathrm{mg} \mathrm{g}^{-1} \mathrm{dw}$ at PLR, a 5.2-fold decrease as compared to control. It was $3.10 \pm$ $0.06 \mathrm{mg} \mathrm{g}^{-1} \mathrm{dw}$ in Batem 56-55 at PLR, a 1.9 fold decrease as compared to control.

Total carotenoid (Car) content increased in Batem 51-52 and Batem 56-55 at LR compared to the controls. Total Car contents in rolled leaves of Batem 51-52 (1.30 $\pm 0.01 \mathrm{mg} \mathrm{g}^{-1}$ $\mathrm{dw})$ and Batem 56-55 $\left(1.9 \pm 0.01 \mathrm{mg} \mathrm{g}^{-1} \mathrm{dw}\right)$ were 2.2 and 2.1-fold higher than the controls $\left(0.6 \pm 0.01 \mathrm{mg} \mathrm{g}^{-1} \mathrm{dw}\right.$ and $\left.0.9 \pm 0.02 \mathrm{mg} \mathrm{g}^{-1} \mathrm{dw}\right)$ respectively. In addition, a significant decrease in the Car contents was determined in Batem 51-52 at PLR. The Car content in Batem 51-52 $\left(0.2 \pm 0.04 \mathrm{mg} \mathrm{g}^{-1} \mathrm{dw}\right)$ at PLR was 7.5-fold lower than the control $(0.60 \pm 0.01$ $\mathrm{mg} \mathrm{g}^{-1} \mathrm{dw}$ ) (Fig. 2B).
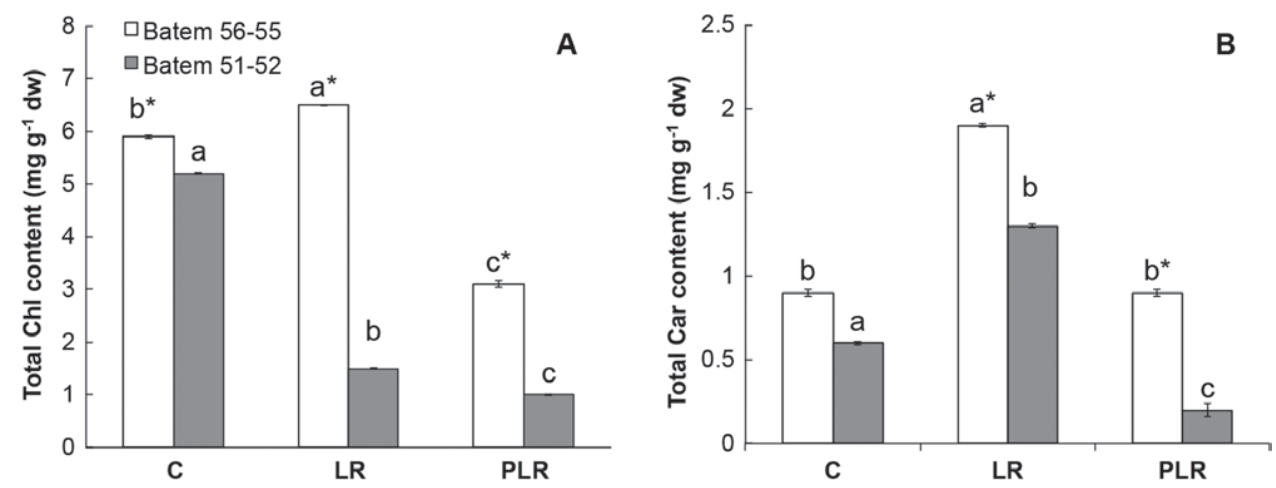

Fig. 2. Changes in photosynthetic pigment contents of maize cultivars. A) total Chl content and B) total Car content; C - control, LR - leaf rolling, PLR - prevention of leaf rolling. Different small letters show statistical differences at $\mathrm{P}<0.05$ among $\mathrm{C}$, LR and PLR of same cultivar. Asterisk denotes significant differences between cultivars. Vertical bars are standard deviation of means.

\section{Thermal imaging}

Leaf temperature increased in both tolerant and sensitive cultivars at LR compared to the controls. Leaf temperature was $21.3 \pm 0.2{ }^{\circ} \mathrm{C}$ in the control group of Batem 51-52 and $20.7 \pm 0.1^{\circ} \mathrm{C}$ in the control group of Batem 56-55. It increased to $21.7 \pm 0.05^{\circ} \mathrm{C}$ in Batem 51-52, and to $21.4 \pm 0.2^{\circ} \mathrm{C}$ in Batem 56-55, at LR. In addition, the leaf temperature at PLR was determined to be higher than that of LR in Batem 56-55. There was no significant difference between LR and PLR in Batem 51-52. The leaf temperature was $21.7 \pm 0.06{ }^{\circ} \mathrm{C}$ in Batem 51-52 and 21.9 $\pm 0.1{ }^{\circ} \mathrm{C}$ in Batem 56-55 at PLR (Fig. 3). 

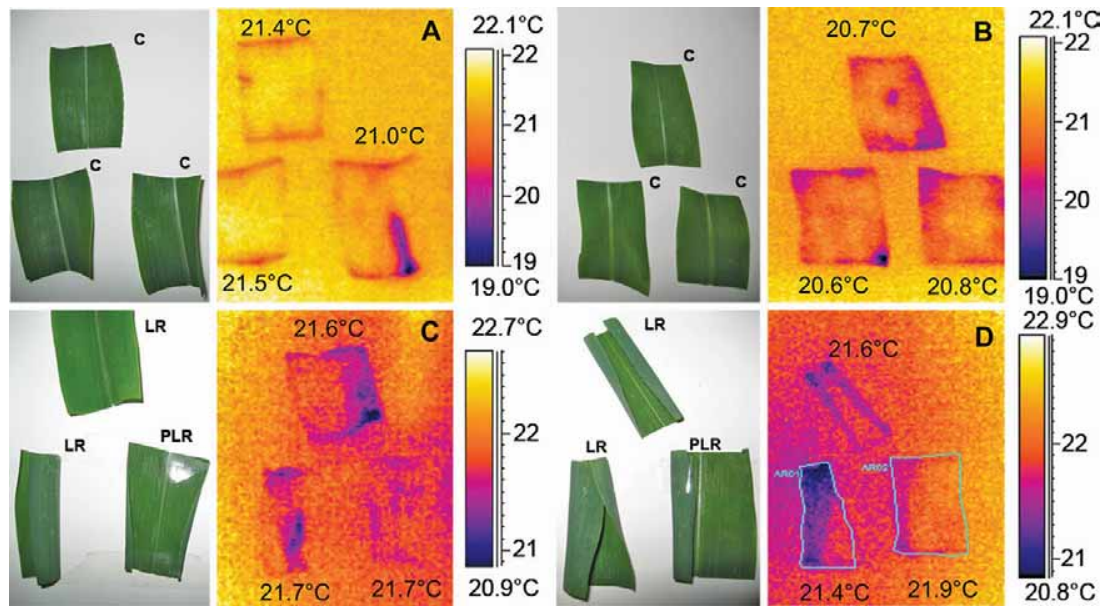

Fig. 3. Thermal images of maize leaves. A) Batem 51-52, sensitive control, B) Batem 56-55, tolerant control, C) Batem 51-52, upon drought stress and D) Batem 56-55, upon drought stress. $\mathrm{C}$ - control, LR - leaf rolling, PLR - prevention of leaf rolling.

\section{Chlorophyll fluorescence parameters}

Maximum quantum yield of PSII photochemistry $\left(\mathrm{F}_{\mathrm{v}} / \mathrm{F}_{\mathrm{m}}\right)$ decreased in both cultivars at $\mathrm{LR}$ (Fig. 4A). The decrease in the $\mathrm{F}_{\mathrm{v}} / \mathrm{F}_{\mathrm{m}}$ was higher in Batem 51-52 than in Batem 56-55. $\mathrm{F}_{\mathrm{v}} / \mathrm{F}_{\mathrm{m}}$ in the rolled leaves of the Batem 51-52 $(0.26 \pm 0.04)$ was 2.9-fold lower than in the control $(0.76 \pm 0.03)$ while $\mathrm{F}_{\mathrm{v}} / \mathrm{F}_{\mathrm{m}}$ in Batem $56-55(0.7 \pm 0.01)$ was 1.1 -fold lower at LR than in the control $(0.76 \pm 0.03)$. Moreover, significant decreases in $\mathrm{F}_{\mathrm{v}} / \mathrm{F}_{\mathrm{m}}$ were determined in both cultivars at PLR compared to the controls. $\mathrm{F}_{\mathrm{v}} / \mathrm{F}_{\mathrm{m}}$ values decreased from 0.76 (control) to 0.16 and 0.6 in Batem 51-52 and Batem 56-55 at PLR, respectively. $\mathrm{F}_{\mathrm{v}} / \mathrm{F}_{\mathrm{m}}$ values in Batem 51-52 and Batem 56-55 were 4.8 and 1.3 fold lower than in their controls (Fig. 4A).

Effective quantum yield of PSII photochemistry $\left(\Phi_{\text {PSII }}\right)$ decreased in Batem 51-52 at LR compared to the control while it did not change in Batem 56-55 (Fig. 4B). As compared to control $(0.6 \pm 0.004)$, a 3-fold decrease in $\Phi_{\text {PII } 2}(0.2 \pm 0.01)$ was determined in Batem 51-52 at LR. A significant decrease in $\Phi_{\text {PSII }}$ was also determined at PLR. The $\Phi_{\text {PSII }}$ in Batem 51-52 and Batem 56-55 diminished to $0.02 \pm 0.003$ and $0.36 \pm 0.01$ at PLR, respectively. The values of $\Phi_{\mathrm{PSII}}$ in Batem 51-52 and Batem 56-55 were 30.0 and 1.5 fold lower than in the control groups, respectively (Fig. 4B).

Non-photochemical quenching (NPQ) increased in rolled leaves of both cultivars compared to the controls (Fig. 4C). Furthermore, the increase in NPQ was higher in Batem 5655 than that of Batem 51-52 at LR. NPQ in Batem 51-52 increased from 0.200 \pm 0.001 to $0.400 \pm 0.004$ (a 2-fold increase). NPQ in Batem 56-55 also increased (from $0.400 \pm 0.001$ to $0.60 \pm 0.01$ ) compared to control, a 1.3 fold increase. In the case of PLR, NPQ decreased in both cultivars significantly compared to the controls. NPQ in Batem 51-52 was $0.100 \pm$ 0.004 at PLR. It was $0.2 \pm 0.01$ in Batem 56-55. The rates of the decreases in NPQ were 2.0 fold in both Batem 51-52 and Batem 56-55 compared to the controls (Fig. 4C).

Electron transport rate (ETR) decreased in Batem 51-52 at LR (Fig. 4D). ETR decreased from $58.0 \pm 0.8 \mu \mathrm{mol} \mathrm{m}^{-2} \mathrm{~s}^{-1}$ (control) to $20.5 \pm 1.2 \mu \mathrm{mol} \mathrm{m} \mathrm{m}^{-2} \mathrm{~s}^{-1}$ at LR, which was 2.8 fold lower than in the control. On the other hand, ETR did not change in Batem 56-55 during LR. 

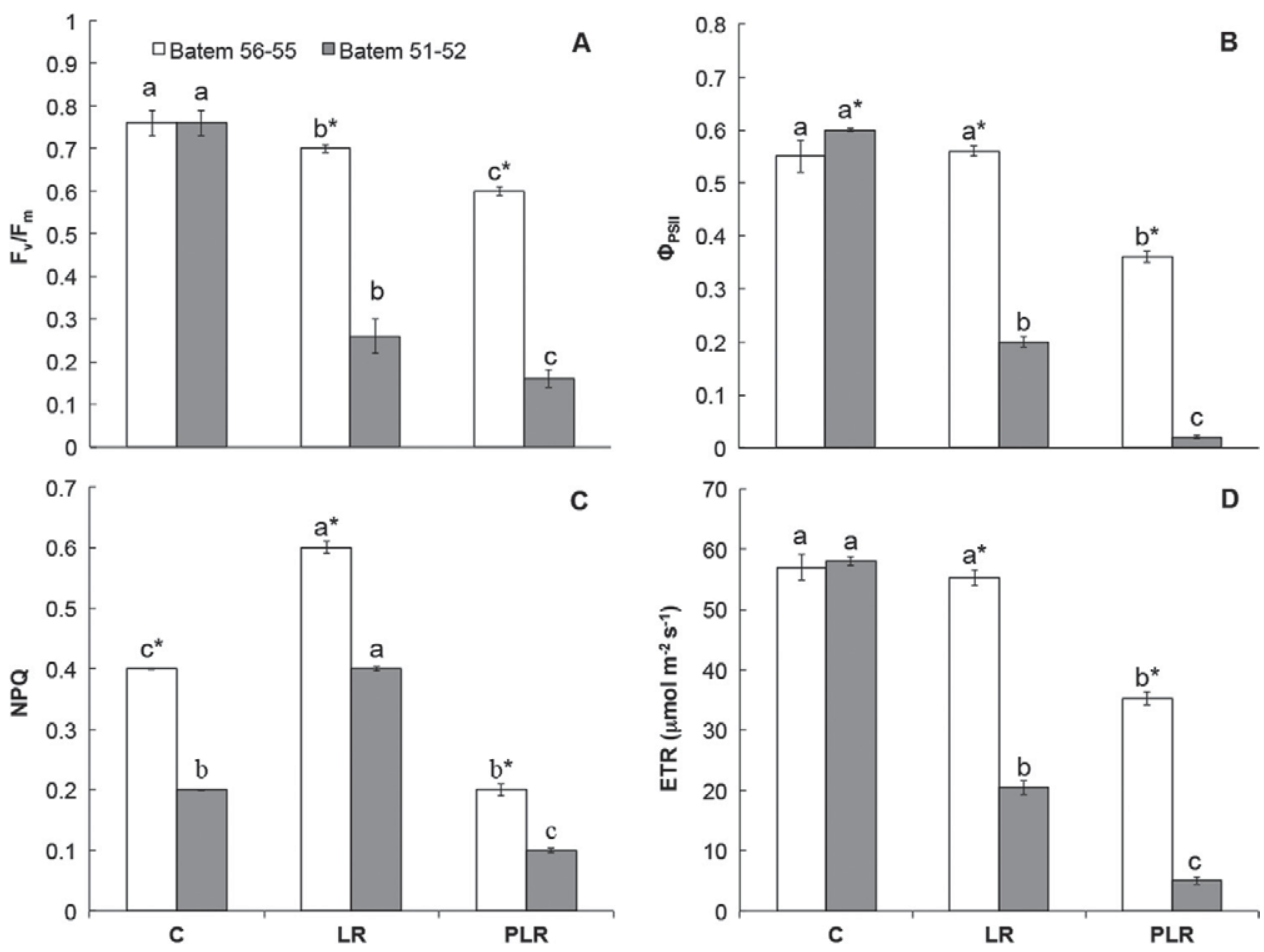

Fig 4. Changes in Chl fluorescence parameters of maize cultivars. A) Fv/Fm - maximum quantum yield of PSII photochemistry B) $\Phi_{\mathrm{PSII}}$ - effective quantum yield of PSII photochemistry, C) NPQ - non-photochemical quenching and D) ETR - electron transport rate; C - control, LR - leaf rolling, PLR - prevention of leaf rolling. Different small letters show statistical differences at $\mathrm{P}<0.05$ among $\mathrm{C}$, LR and PLR of same cultivar. Asterisk denotes significant differences between cultivars. Vertical bars are standard deviation of means.

In the case of PLR, ETR decreased in both cultivars compared to the controls. ETRs in Batem 51-52 and Batem 56-55 were $5 \pm 0.6 \mu \mathrm{mol} \mathrm{m} \mathrm{m}^{-2} \mathrm{~s}^{-1}$ and $35.3 \pm 1.1 \mu \mathrm{mol} \mathrm{m}{ }^{-2} \mathrm{~s}^{-1}$. There were 12.0 and 1.6-fold decreases in Batem 51-52 and Batem 56-55 as compared controls, respectively (Fig. 4D).

\section{Photosynthetic gas exchange measurements}

Stomatal conductance $\left(\mathrm{g}_{\mathrm{s}}\right)$ diminished in both cultivars at LR. $\mathrm{g}_{\mathrm{s}}$ in Batem 51-52 decreased from $180 \pm 2.2 \mathrm{mmol} \mathrm{m}^{-2} \mathrm{~s}^{-1}$ (control) to $23 \pm 0.5 \mathrm{mmol} \mathrm{m}^{-2} \mathrm{~s}^{-1}$ (a 7.8-fold decrease). The decrease in $g_{s}$ was greater in Batem 51-52 than in Batem 56-55 at LR (Fig. 5A). $g_{s}$ in Batem 56-55 diminished from $170 \pm 1.3 \mathrm{mmol} \mathrm{m}^{-2} \mathrm{~s}^{-1}$ to $92 \pm 2.7 \mathrm{mmol} \mathrm{m}^{-2} \mathrm{~s}^{-1}$, which was a 1.9-fold decrease. Remarkable decreases in $\mathrm{g}_{\mathrm{s}}$ were measured in both cultivars at PLR compared to the controls. $g_{s}$ values in Batem 51-52 and Batem 56-55 were $5 \pm 0.4 \mathrm{mmol} \mathrm{m}^{-2}$ $\mathrm{s}^{-1}$ and $50 \pm 2.5 \mathrm{mmol} \mathrm{m}^{-2} \mathrm{~s}^{-1}$, respectively at PLR. $\mathrm{g}_{\mathrm{s}}$ in Batem 51-52 and Batem 56-55 were 36 and 3.4-fold lower than the controls, respectively.

Transpiration rate (E) decreased in both cultivars at LR compared to the controls (Fig. 5B). E in Batem 51-52 decreased from $5.3 \pm 0.1 \mathrm{mmol} \mathrm{m}^{-2} \mathrm{~s}^{-1}$ (control) to $1.3 \pm 0.1 \mathrm{mmol}$ 
$\mathrm{m}^{-2} \mathrm{~s}^{-1}$. E in Batem 56-55 was reduced from $3.7 \pm 0.2 \mathrm{mmol} \mathrm{m}^{-2} \mathrm{~s}^{-1}$ (control) to $2.6 \pm 0.3$ mmol m $\mathrm{m}^{-2}$. Decrease in E was higher in Batem 51-52 than in Batem 56-55 at LR. The rates of decreases were 1.4 and 4.1 in Batem 56-55 and Batem 51-52 compared to control, respectively. The decreases in E were more at PLR than those of LR as compared to controls. E values were $0.110 \pm 0.007 \mathrm{mmol} \mathrm{m}^{-2} \mathrm{~s}^{-1}$ and $0.37 \pm 0.02 \mathrm{mmol} \mathrm{m}^{-2} \mathrm{~s}^{-1}$ in Batem 51-52 and Batem 56-55 at PLR, respectively (Fig. 5B). E values in Batem 51-52 and Batem 56-55 were 48 and 10-fold lower than the control groups, respectively.

Photosynthetic rate $\left(\mathrm{P}_{\mathrm{N}}\right)$ decreased in both cultivars at LR compared to the controls (Fig. 5C). $\mathrm{P}_{\mathrm{N}}$ values were reduced from $11.5 \pm 0.4 \mu \mathrm{mol} \mathrm{m}{ }^{-2} \mathrm{~s}^{-1}$ (control) to $1.2 \pm 0.04 \mu \mathrm{mol} \mathrm{m}^{-2}$ $\mathrm{s}^{-1}$ in Batem 51-52. It was reduced from $15.9 \pm 0.6 \mu \mathrm{mol} \mathrm{m}^{-2} \mathrm{~s}^{-1}$ (control) to $7.1 \pm 0.4 \mu \mathrm{mol}$ $\mathrm{m}^{-2} \mathrm{~s}^{-1}$ in Batem 56-55 at LR. $\mathrm{P}_{\mathrm{N}}$ values were reduced at the rates of 9.6 and 2.3 in Batem 51-52 and Batem 56-55 at LR compared to their controls, respectively. $\mathrm{P}_{\mathrm{N}}$ decreased more in both cultivars at PLR than LR compared to control. $\mathrm{P}_{\mathrm{N}}$ values were $1.03 \pm 0.06 \mu \mathrm{mol} \mathrm{m}^{-2}$ $\mathrm{s}^{-1}$ and $6.3 \pm 0.14 \mu \mathrm{mol} \mathrm{m} \mathrm{m}^{-2} \mathrm{~s}^{-1}$ in Batem 51-52 and Batem 56-55 at PLR, respectively (Fig. 5C). The rates of decrease in $\mathrm{P}_{\mathrm{N}}$ were 11.1 and 2.5 in Batem 51-52 and Batem 56-55 at PLR compared to the controls, respectively.

Intracellular $\mathrm{CO}_{2}$ concentration $\left(\mathrm{C}_{\mathrm{i}}\right)$ was reduced by drought at $\mathrm{LR}$ (Fig. 5D). $\mathrm{C}_{\mathrm{i}}$ in Batem 51-52 decreased from $428.0 \pm 8.6 \mu \mathrm{mol} \mathrm{mol}^{-1}$ (control) to $378.0 \pm 11.6 \mu \mathrm{mol} \mathrm{mol}^{-1}$. It was reduced from $347.0 \pm 4.9 \mu \mathrm{mol} \mathrm{mol}{ }^{-1}$ to $305.0 \pm 16.3 \mu \mathrm{mol} \mathrm{mol}^{-1}$ in Batem 56-55. The rates of the decrease in $\mathrm{C}_{\mathrm{i}}$ values were 1.1 and 1.1 in Batem 51-52 and Batem 56-55 at LR compared to their controls. The reductions in $\mathrm{C}_{\mathrm{i}}$ at PLR were higher than those of LR compared to control. $\mathrm{C}_{\mathrm{i}}$ values were $358.0 \pm 9.0 \mu \mathrm{mol} \mathrm{mol}^{-1}$ and $275.0 \pm 2.1 \mu \mathrm{mol} \mathrm{mol}^{-1}$ in Batem 51-52 and Batem 56-55 at PLR, respectively. The rate of the decrease in $\mathrm{C}_{\mathrm{i}}$ was 1.2 in Batem 51-52 compared to the control while it was 1.3 in Batem 56-55 at PLR.
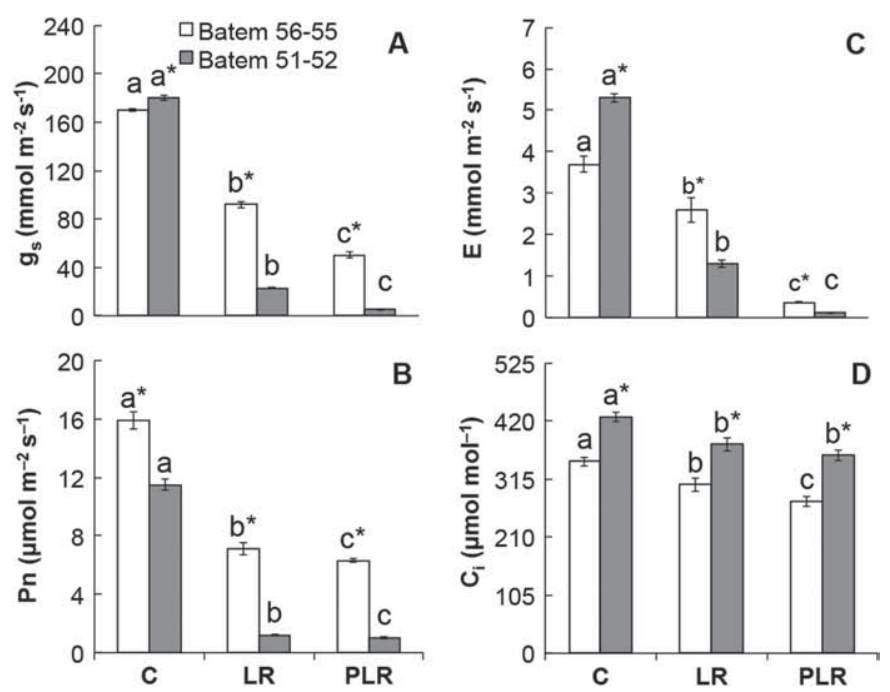

Fig. 5. Changes in photosynthetic gas exchange parameters of maize cultivars. A) $g_{s}-$ stomatal conductance, $\mathrm{B}) \mathrm{P}_{\mathrm{n}}$ - net photosynthetic rate, C) $\mathrm{E}$ - transpiration and D) $\mathrm{C}_{\mathrm{i}}-$ intracellular $\mathrm{CO}_{2}$; $\mathrm{C}$ - control, LR - leaf rolling, PLR - prevention of leaf rolling. Different small letters show statistical differences at $\mathrm{P}<0.05$ among $\mathrm{C}, \mathrm{LR}$ and PLR of same cultivar. Asterisk denotes significant differences between cultivars. Vertical bars are standard deviation of means. 


\section{Rubisco activity}

Rubisco activity in Batem 51-52 was higher than Batem 56-55. Rubisco activity decreased in both cultivars at LR compared to the controls. Rubisco activity in Batem 51-52 decreased from $1286.0 \pm 15.0 \mathrm{U} \mathrm{mg}^{-1}$ protein (control) to $869.0 \pm 24.0 \mathrm{U} \mathrm{mg}^{-1}$ protein. It was reduced from $464.0 \pm 13.0 \mathrm{U} \mathrm{mg}^{-1}$ protein (control) to $303 \pm 11.0 \mathrm{U} \mathrm{mg}^{-1}$ protein for Batem 56-55 (Fig. 6A). There was a 1.5-fold reduction in the Rubisco activity in both cultivars at LR compared to their controls. Rubisco activities determined at LR were higher than PLR for both cultivars. Rubisco activities were $557 \pm 19.0 \mathrm{U} \mathrm{mg}^{-1}$ protein and $128.0 \pm 9.0 \mathrm{U} \mathrm{mg}^{-1}$ protein in Batem 51-52 and Batem 56-55 at PLR, respectively. The reductions in the activities were higher at PLR than LR compared to the controls (Fig. 6). The reductions in the activities were 2.3-fold and 3.6-fold in Batem 51-52 and Batem 56-55 at PLR compared to the controls, respectively.

\section{Rubisco content}

Rubisco content in Batem 51-52 was higher than Batem 56-55 in control plants (Fig. 6B). It was $0.9 \pm 0.05 \mathrm{pmol}_{\mu \mathrm{g}}{ }^{-1}$ protein in Batem 51-52 and $0.4 \pm 0.01 \mathrm{pmol} \mu \mathrm{g}^{-1}$ protein in Batem 56-55. Rubisco contents of both cultivars decreased at LR as compared to control. They were $0.2 \pm 0.008 \mathrm{pmol} \mu \mathrm{g}^{-1}$ protein in Batem 51-52 (4.5-fold lower than control) and $0.2 \pm 0.002$ pmol $\mu \mathrm{g}^{-1}$ protein in Batem 56-55 (2-fold lower than control). Rubisco contents of the cultivars at PLR were lower than those of LR plants. There was $0.002 \pm 0.0005$ pmol

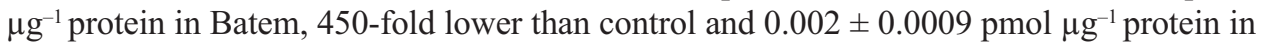
Batem 56-55, 200-fold lower than control.
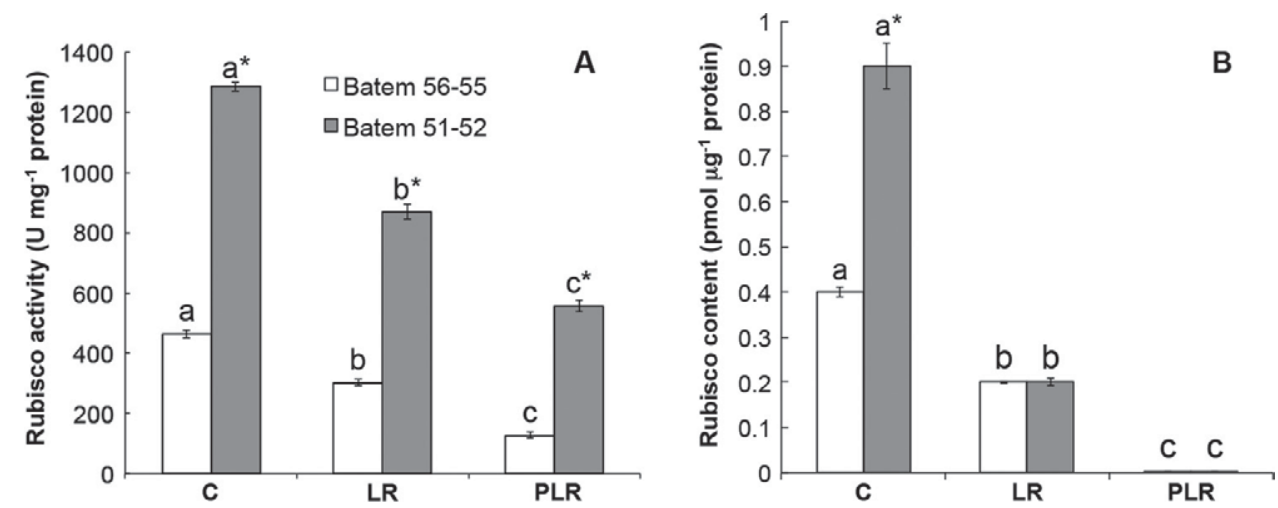

Fig. 6. Changes in Rubisco activity (A) and content (B) of maize cultivars; C - control, LR - leaf rolling, PLR - prevention of leaf rolling. Different small letters show statistical differences at $\mathrm{P}<0.05$ among $\mathrm{C}, \mathrm{LR}$ and PLR of same cultivar. Asterisk denotes significant differences between cultivars. Vertical bars are standard deviation of means.

\section{Agronomic characteristics}

As compared to control, ear weights were reduced in both cultivars at LR. Ear weights decreased from and $64.0 \pm 0.5 \mathrm{~g}$ to $40.0 \pm 0.5 \mathrm{~g}$ in Batem 51-52 and $46.0 \pm 0.4 \mathrm{~g}$ to $25.0 \pm$ $0.7 \mathrm{~g}$ in Batem 56-55 at LR, respectively. The reduction in the ear weight was higher in 
Batem 51-52 (2.6 fold) than Batem 56-55 (1.2 fold) at LR (Fig. 7A). Ear weights decreased more at PLR than LR compared to the controls. Ear weights in Batem 51-52 and Batem 5655 were $21 \pm 1.1 \mathrm{~g}$ and $40 \pm 0.5 \mathrm{~g}$ at PLR, respectively. The decreases in ear weight were 3.0 and 1.5 fold in Batem 51-52 and Batem 56-55 as compared to their controls, respectively. One hundred-kernel weight also declined at LR. The kernel weight in Batem 51-52 diminished from $45.0 \pm 2.3$ (control) to $15 \pm 0.4 \mathrm{~g}$ at LR. It was not changed in Batem 56-55. The reduction in 100-kernel weight in Batem 51-52 was 3.0 fold compared to the control (Fig. 7B). The decreases were more pronounced in both cultivars at PLR compared to the controls. Decreases in 100-kernel weights of Batem 51-52 and Batem 56-55 were 3.5 and 1.2 fold at PLR compared to the controls, respectively (Fig. 7B).
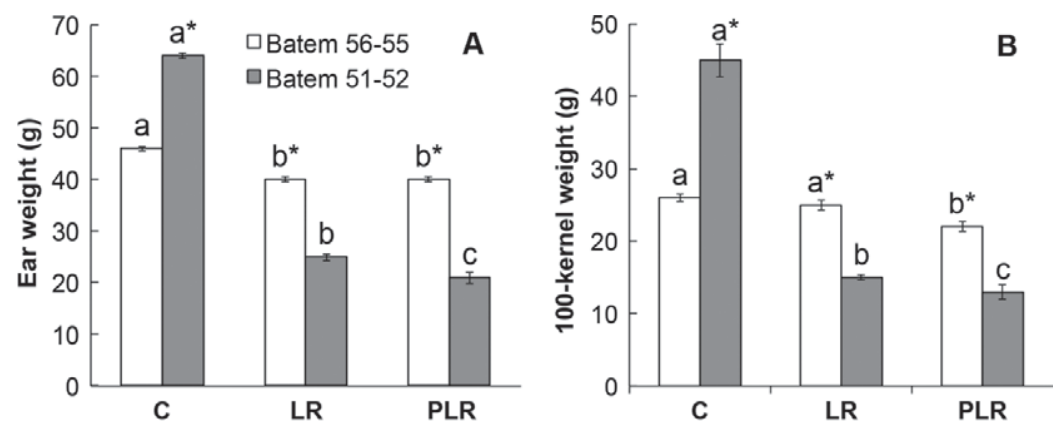

Fig. 7. Changes in agronomic characteristics of maize cultivars. A) ear weight and B) 100-kernel weight; C - control, LR - leaf rolling, PLR - prevention of leaf rolling. Different small letters show statistical differences at $\mathrm{P}<0.05$ among $\mathrm{C}, \mathrm{LR}$ and PLR of same cultivar. Asterisk denotes significant differences between cultivars. Vertical bars are standard deviation of means.

\section{Discussion}

In the present study, leaf water potential in rolled leaves of drought sensitive maize cultivar was reduced by drought. Confirming our study, decreases in leaf water potential during LR were also reported in maize and C. setosa plants subjected to drought stress (TeRzI et al. 2009, SARUHAN et al. 2012). On the other hand, plants having LR mechanism were reported to exhibit a resistance to drought and high temperature and had higher water use efficiency (KADIOGLu et al. 2012). That the decrease in leaf water content in our study was enhanced by PLR compared to LR suggested that LR might be a water-saving regulatory mechanism and may protect maize photosynthesis from drought stress.

To evaluate effects of environmental stress on growth and yield, Chl content and Chl fluorescence parameters can be measured because these traits are related with carbon exchange rate (FRACHEBOUD et al. 2004). The effect of LR on photosynthetic pigment content was studied in maize under drought stress. Chl content decreased under drought in the sensitive cultivar at LR in our study while it increased in the tolerant one. Similarly, a high decrease in pigment content was reported in a sensitive maize cultivar under drought stress (CHugh et al. 2013). The increase in pigment concentration could be related to decreased leaf surface and assembling chlorophylls on less area of leaf (TouRIAN et al. 2013). Relation 
between LR and photosynthetic pigment content was shown under drought stress in $C$. setosa (NAR et al. 2009). During early LR, a decrease in photosynthetic pigment content was observed. However, it approached control values in the late LR situation under severe drought stress. In our study, significant decreases in pigment content were observed at PLR compared to LR. These significant reductions in the pigment content could be related to changes in microclimate parameters such as irradiance and temperature differences, which might be created by the LR. However, the PLR may disrupt humid environment formed in rolled leaves, which have low temperature inside. Thermal images of maize leaves indicated that rolled leaves were cooler than artificially opened leaves. Leaf temperature of rolled maize leaves was $21.4 \pm 0.2^{\circ} \mathrm{C}$ while the temperature of artificially opened leaves was 21.9 $\pm 0.1{ }^{\circ} \mathrm{C}$. In addition, reduced irradiance upon the leaf surfaces (PAR) due to LR was reversed by PLR in our study. PAR in control $(1081 \pm 0.2)$ decreased to $295 \pm 42$ during LR then increased to $1092 \pm 20$ during PLR. Therefore we concluded that LR might prevent light damage on PSII by reducing leaf exposure to light.

Chlorophyll $a$ fluorescence provides information about the effects of LR on photosynthetic apparatus under drought stress (NAR et al. 2009). Thus, changes in fluorescence parameters were investigated in this study. One of those parameters, $F_{v} / F_{m}$ has been widely used to detect changes in the photosynthetic apparatus due to stress (BAKER and ROSENQVIST 2004). In other words, changes in the fluorescence yield reflect changes in photochemical efficiency. Low $\mathrm{F}_{\mathrm{v}} / \mathrm{F}_{\mathrm{m}}$ values in plants under stress indicate damage to the PSII reaction center (NAR et al. 2009). In this study, the decrease of $F_{v} / F_{m}$ in the sensitive cultivar was more pronounced than in the tolerant cultivar during LR, indicating a higher drought tolerance in the latter cultivar. In addition, higher decreases in $\mathrm{F}_{\mathrm{v}} / \mathrm{F}_{\mathrm{m}}$ at PLR indicated that LR might have a protective role on photosynthetic apparatus. However, no change in $\mathrm{F}_{\mathrm{v}} / \mathrm{F}_{\mathrm{m}}$ was found in C. setosa, a drought tolerant plant (TERZI and KADIOGLU 2006), during LR (NAR et al. 2009).

Increase in NPQ resulting from drought stress is a well-known phenomenon (EFEOĞLU et al. 2009, HuANG et al. 2013). In the present study, NPQ increase during LR indicated the thermal dissipation of energy load on the leaves, perhaps preventing photo damage. Maize genotypes were found to conserve their photosystems from adverse effects of drought by increasing NPQ (DE SouzA et al. 2013). Carotenoids are known as accessory photosynthetic pigments protecting the chlorophylls from oxidative stress damage during photosynthesis, dissipating energy through non-photochemical quenching and having an important role in the xanthophyll cycle (DE SouzA et al. 2013). The increases in NPQ and Car content on rolled leaves of maize indicated thermal dissipation of excess energy in our study, which supported this hypothesis. Decreases in Car content and NPQ at PLR also supported the protective role of LR on the photosynthetic system.

Reduction in effective quantum yield of PSII photochemistry was observed in sensitive cultivar at LR in this study. Down-regulation of electron transport can be estimated by decreased in $\Phi_{\text {PSII }}$. This decrease can also be related with increases in excitation energy quenching in the PSII antennae (HoRTON et al. 1996). Consequently, the increase of NPQ in the sensitive cultivar was lower than in the tolerant, resulting in more energy on PSII and also more damage under drought. The decreases in $\Phi_{\text {PSII }}$ showed increased excitation energy quenching process in the PSII antennae and the regulation of electron transport. Therefore, the increase in NPQ during LR may cause a decrease in $\Phi_{\text {PSII }}$. On the other hand, high NPQ in the tolerant cultivar did not affect $\Phi_{\text {PSII }}$ at LR. Increased Chl content in the tolerant cultivar 
at LR might compensate for energy loss through NPQ in the tolerant cultivar. In addition, $\Phi_{\text {PSII }}$ at PLR was reduced more than LR in our study. The decrease in $\Phi_{\text {PSII }}$ at PLR could also be a proof for a protective role of LR on PSII.

A decline in electron transport rate was determined in the present study. This decrease in ETR may be associated with the increased trans-thylakoid $\Delta \mathrm{pH}$. This change in $\Delta \mathrm{pH}$ causes the xanthophyll de-epoxidation that follows increasing thermal dissipation of energy when photosynthesis is reduced (Lu and ZHANG 1999). In addition, photochemical down-regulation under stress conditions could cause reductions in ETR. Drought stress was recorded to limit photosynthetic machinery of six maize genotypes (CRUZ DE CARVALHO et al. 2011). On the other hand, higher decreases in ETR during PLR supported the hypothesis that LR could be a protective mechanism for photosystems under drought.

Stomatal conductance is one of the parameters that affect photosynthesis under drought stress (SidDiQue et al. 1999, JiAnG et al. 2006). Because $\mathrm{g}_{\mathrm{s}}$ restricts $\mathrm{CO}_{2}$ uptake, it is considered to be one of the main reasons for reduced photosynthesis (ASHRAF and HARRIS 2013). In this respect, reduction in photosynthesis probably depends more on $\mathrm{CO}_{2}$ in the chloroplast than on leaf water potential (MEDRANo et al. 2002). In our study, $g_{s}$ was reduced by drought in rolled leaves of maize plants probably due to reduction in leaf water potential. A decrease in $\mathrm{g}_{\mathrm{s}}$ and $\Psi_{\text {leaf }}$ and a positive correlation between them were reported in maize plants under water stress (CRUZ DE CARVAlho et al. 2011; Zia et al. 2011). On the other hand, sharp decreases in $g_{s}$ and increases in leaf temperature following PLR in our study suggest that LR may maintain $\mathrm{CO}_{2}$ uptake by creating a cool and humid environment inside the rolled leaf thus allowing some of stomata to remain open. Similarly, $\mathrm{g}_{\mathrm{s}}$ values were found to be higher at adaxial (inner) surfaces of the rolled leaves than those of PLR during drought stress (NAR et al. 2009)

In the present study, the net photosynthetic rate decreased in rolled leaves of both maize cultivars under drought. However, the reduction in $\mathrm{P}_{\mathrm{N}}$ of the tolerant cultivar was less than in the sensitive cultivar. Similarly, photosynthesis of drought-tolerant and sensitive maize cultivars responded to drought in different ways (CRUZ DE CARVALHO et al. 2011). In addition to $\mathrm{P}_{\mathrm{N}}$ and transpiration rate, intracellular $\mathrm{CO}_{2}$ concentration also decreased in rolled leaves of maize cultivars in the present study. In addition, similar results were reported for drought tolerant and sensitive maize cultivars subjected to drought stress (ZHANG and LiU 2009). Stomatal and non-stomatal factors cause reduction in photosynthesis. In the present study, decreases in $\mathrm{P}_{\mathrm{N}}, \mathrm{g}_{\mathrm{s}}, \mathrm{C}_{\mathrm{i}}$ and $\mathrm{E}$ indicated that reduction in photosynthesis was due to stomatal factors. However, as compared to LR, notable reductions in all gas exchange parameters occurred following PLR. These differences may indicate that LR may minimize photosynthetic losses due to drought stress, functioning as a protective mechanism.

The effect of LR on the activity of the $\mathrm{CO}_{2}$-fixing enzyme Rubisco was investigated in the current study. Reductions in the Rubisco activity were observed in rolled leaves of both cultivars. Furthermore, Rubisco activity was higher in the sensitive than in the tolerant cultivar. This might be related to the high amount of Rubisco in the drought sensitive cultivar. On the other hand, high content of inactive Rubisco in tolerant cultivar at LR might be a reason for low activity even if tolerant and sensitive cultivar has same amount of Rubisco. In addition the decrease in Rubisco activity in our study may be a result of stomatal closure due to long-term drought stress. Stomata closure reduces photoassimilates and concentration of $\mathrm{C}_{\mathrm{i}}$ (BACZEK-KwINTA et al. 2010) leading to Rubisco deactivation (CHAVES and OliveIRA 2004). Decrease in $C_{i}$ in our study supports the hypothesis that the reduction in Rubisco 
activity may be a result of stomatal closure. As compared to LR, higher decreases in Rubisco activity after PLR indicate that the LR mechanism may preserve activity of $\mathrm{CO}_{2}$ fixation enzymes.

Drought stress causes reductions in maize development and growth (SHIRAZI et al. 2011). XIAO et al. (2005) and TI-DA et al. (2006) reported that cob characters especially number of kernels of corncob, ear weight and 100-kernel weight were decisive factors for maize yield loss under drought stress. Decreases in kernel weight of corn cultivars subjected to drought were also observed previously (KHALILY et al. 2010). Decreases in ear weight and 100-kernel weights at PLR indicated that LR could be a mechanism to reduce yield loss in our study.

In conclusion, leaves were rolled in drought tolerant maize cultivars later than in sensitive cultivars under drought stress. The results showed that monitoring of LR would be useful for the early detection of drought stress. Significant decreases in Chl fluorescence parameters of PLR plants compared to LR implied that LR might protect the photosynthesis under severe drought. Also, the study showed that LR allowed photosynthesis to occur by protecting PSII efficiency and Rubisco activity under severe drought by maintaining leaf water content. 100-kernel and ear weights at LR were less affected by drought as compared to PLR. LR might also be important for maize yield under drought stress. Therefore, we suggest that maize cultivars with late LR may be planted in order to avoid yield losses resulting from drought.

\section{Acknowledgements}

This work was supported by the Scientific and Technological Research Council of Turkey (TUBITAK, TBAG 110T472). The authors are grateful to Dr Şemsettin KULAÇ (Faculty of Forestry, Düzce University) for his help on the rain-out-shelter construction.

\section{References}

Arnon, D. I., 1949: Copper enzymes in isolated chloroplasts. Polyphenoloxidase in Beta vulgaris. Plant Physiology 24, 1-15.

Ashraf, M., Harris P. J. C., 2013: Photosynthesis under stressful environments: An overview. Photosynthetica 51, 163-190.

Baczek-Kwinta, R., Adamska, A., Seidler-Lozykowska, K., Tokarz, K., 2010: Does the rate of german chamomile growth and development influence the response of plants to soil drought? Biologia 65, 837-842.

Bai, L. P., Sui, F. G., Ge, T. D., Sun, Z. H., Lu, Y. Y., Zhou, G. S., 2006: Effect of soil drought stress on leaf water status, membrane permeability and enzymatic antioxidant system of maize. Pedosphere 16, 326-332.

BAKer, N. R., Rosenqvist, E., 2004: Application of chlorophyll fluorescence can improve crop production strategies: an examination of future possibilities. Journal of Experimental Botany 55, 1607-1621.

BAnZiger, M., ArAus, J. L., 2007: Recent advances in breeding maize for drought and salinity stress tolerance. In: Jenks, M. A., Hasegawa, P. M., Jain, S. M. (eds.), Advances in molecular breeding toward drought and salt tolerant crops, 587-601. Springerlink, Berlin. 
BRADFORD, M. M., 1976: A rapid and sensitive method for the quantitation of microgram quantities of protein utilizing the principle of protein-dye binding. Analytical Biochemistry $72,248-254$.

Chaves, M. M., Flexas, J., Pinheiro, C., 2009: Photosynthesis under drought and salt stress: regulation mechanisms from whole plant to cell. Annals of Botany 103, 551-560.

Chaves, M. M., Oliveira, M. M., 2004: Mechanisms underlying plant resilience to water deficits: prospects for water-saving agriculture. Journal of Experimental Botany 407, 2365-2379.

Chugh, V., Kaur, N., Grewal, M. S., Gupta, A. K., 2013: Differential antioxidative response of tolerant and sensitive maize (Zea mays L.) genotypes to drought stress at reproductive stage. Indian Journal of Biochemistry and Biophysics 50, 150-158.

Corlett, J. E., Jones, H. G., Mascacci, A., Masojidek, J., 1994: Water deficit, leaf rolling and susceptibility to photoinhibition in field grown sorghum. Physiologia Plantarum 92, 423-430.

Cruz de Carvalho, R., Cunha, A., Marques da Silva, J., 2011: Photosynthesis by six Portuguese maize cultivars during drought stress and recovery. Acta Physiologiae Plantarum 33, 359-374.

de Souza, T. C., Magalhaes, P. C., de Castro, E. M., de Albuquerque, P. E. P., Marabesi, M. A., 2013: The influence of ABA on water relation, photosynthesis parameters, and chlorophyll fluorescence under drought conditions in two maize hybrids with contrasting drought resistance. Acta Physiologiae Plantarum 35, 515-527.

EfeoĞlu, B., Ekmekçı, Y., ÇıçeK, N., 2009: Physiological responses of three maize cultivars to drought stress and recovery. South African Journal of Botany 75, 34-42.

Fracheboud, Y., Jompuk, C., Ribaut, J. M., Stamp, P., Leipner, J., 2004: Genetic analysis of cold-tolerance of photosynthesis in maize. Plant Molecular Biology 56, 241-253.

Genty, B., Briantais, J. M., Baker, N. R., 1989: The relationship between the quantum yield of photosynthetic electron transport and quenching of chlorophyll fluorescence. Biochimica et Biophysica Acta 990, 87-92.

Grzesiak, M. T., Waligorski, P., Janowiak, F., Marcinska, I., Hura, K., Szczyrek, P., GŁab, T., 2013: The relations between drought susceptibility index based on grain yield (DSIGY) and key physiological seedling traits in maize and triticale genotypes. Acta Physiologiae Plantarum 35, 549-565.

Heath, R. L., Packer, L., 1968: Photoperoxidation in isolated chloroplasts. I. kinetics and stoichiometry of fatty acid peroxidation. Archives of Biochemistry and Biophysics 125, 189-198.

Horton, P., Ruban, A. V., Walters, R. G., 1996: Regulation of light harvesting in green plants. Annual Review of Plant Physiology and Plant Molecular Biology 47, 655-684.

Huang, C., Zhao, S., Wang, L., Anuum, S. A., Chen, M., Zhou, H., Zou, C., 2013: Alteration in chlorophyll fluorescence, lipid peroxidation and antioxidant enzymes activities in hybrid ramie (Boehmeria nivea L.) under drought stress. Australian Journal of Crop Science 7, 594-599.

JiAng, Q., Roche, D., Monaco, T. A., Hole, D., 2006: Stomatal conductance is a key parameter to assess limitations to photosynthesis and growth potential in barley genotypes. Plant Biology 8, 515-521. 
Kadioglu, A., Terzi, R., Saruhan, N., Saglam, A., 2012: Current advances in the investigation of leaf rolling caused by biotic and abiotic stress factors. Plant Science 182, 42-48.

Khalily, M., Moghaddam, M., Kanouni, H., Asheri, E., 2010: Dissection of drought stress as a grain production constraint of maize in Iran. Asian Journal of Crop Science 2, 60 69.

LAEMmLi, U. K., 1970: Cleavage of structural proteins during the assembly of the head of bacteriophage T4. Nature 227, 680-685.

LANG, Y. Z., Zhang, Z. J., Gu, X. Y., YANG, J. C., ZhU, Q. S., 2004: A Physiological and ecological effect of crimpy leaf character in rice (Oryza sativa L.) II. photosynthetic character, dry mass production and yield forming. Acta Agronomica Sinica 30, 883-887.

Liu, Y., Subhash, C., Yan, J., Song, C., ZhaO, J., Li, J., 2011: Maize leaf temperature responses to drought: Thermal imaging and quantitative trait loci (QTL) mapping. Environmental and Experimental Botany 71, 158-165.

Lu, C. M., Zhang, J. H., 1999: Effects of water stress on photosystem II photochemistry and its thermostability in wheat plants. Journal of Experimental Botany 50, 1199-1206.

MA, Z., Cooper, C., Kim, H. J., JAnick-Buckner, D., 2009: A study of rubisco through western blotting and tissue printing techniques. CBE Life Sciences Education 8, 140-146.

Medrano, H., Escalona, J. M., Bota, J., Gulias, J., Flexas, J., 2002: Regulation of photosynthesis of $\mathrm{C}_{3}$ plants in response to progressive drought: the interest of stomatal conductance as a reference parameter. Annals of Botany 89, 895-905.

Nar, H., Saglam, A., Terzi, R., Várkonyi, Z., Kadioglu, A., 2009: Leaf rolling and photosystem II efficiency in Ctenanthe setosa exposed to drought stress. Photosynthetica 47, 429-436.

Premachandra, G. S., Saneoka, H., Fujita, K., Ogata, S., 1993: Water stress and potassium fertilization in field grown maize (Zea mays L.): Effects of leaf water relations and leaf rolling. Journal of Agronomy and Crop Science 170, 195-201.

Salvi S., Sponza, G., Morgante, M., Tomes, D., Niu, X., Fengler, K. A., Meeley, R., Ananiev, E. V., Svitashev, S., Bruggemann, E., Li, B., Hainey, C. F., Radovic, S., Zaina, G., Rafalski, J. A., Tingey, S. V., Miao, G. H., Phillips, R. L., Tuberosa, R., 2007: Conserved noncoding genomic sequences associated with a flowering-time quantitative trait locus in maize. Proceedings of The National Academy of Sciences of The United States of America 104, 11376-11381.

Saruhan, N., Saglam, A., Kadioglu, A., 2012: Salicylic acid pretreatment induces drought tolerance and delays leaf rolling by inducing antioxidant systems in maize genotypes. Acta Physiologiae Plantarum 34, 97-106.

Sawada, S. S., Sato, M., Kasai, A., Yaochi, D., Kameya, Y., Matsumoto, I., Kasai, M., 2003: Analysis of the feed-forward effects of sink activity on the photosynthetic sourcesink balance in single-rooted sweet potato leaves. I. Activation of RuBPacse through the development of sinks. Plant and Cell Physiology 44, 190-197.

Setter, T. L., Flannigan, B., Melkonian, J., 2001: Loss of kernel set due to water deficit and shade in maize. Crop Science 41, 1530-1540.

Shirazi, S. M., Sholichin, M., Mohammed, J., Shatirah, A., Mokhtar, A., 2011: Effects of different irrigation regimes and nitrogenous fertilizer on yield and growth parameters of maize. International Journal of Physical Sciences 6, 677-683. 
Siddique, M. R. B., Hamid, A., Islam, M. S., 1999: Drought stress effects on photosynthetic rate and leaf gas exchange of wheat. Botanical Bulletin of Academia Sinica 40, 141145 .

Singh, B. N., MackiLl, D. J., 1990: Genetics of leaf rolling under drought stress. Proceedings of the 2nd International Rice Genetics Symposium, Philippines, 159-166.

Terzi, R., Kadioglu, A., 2006: Drought stress tolerance and antioxidant enzyme system in Ctenanthe setosa. Acta Biologica Cracovensia Series Botanica 48, 89-96.

Terzi, R., Saruhan, N., Saglam, A., Nar, H., Kadioglu, A., 2009: Photosystem II functionality and some antioxidant enzyme changes during leaf rolling in post-stress emerging Ctenanthe setosa exposed to water deficit stress. Acta Biologica Hungarica 60, 417431.

Ti-dA, G. E., Sui, F. G., Bai, L. P., Lu, Y. Y., Zhou, G., 2006: Effects of water stress on the protective enzyme activities and lipid peroxidation in root and leaves of summer maize. Agricultural Sciences in China 5, 291-298.

Tourian, N., Sinaki, J. M., Hasani, N., Madani, H., 2013: Change in photosynthetic pigment concentration of wheat grass (Agropyron repens) cultivars response to drought stress and foliar application with Chitosan. International Journal of Agronomy and Plant Production 4, 1084-1091.

Vollsnes, A. V., Berglen Eriksen, A., Otterholt, E., Kvaal, K., Oxaal, U., Futsaether, C. M., 2009: Visible foliar injury and infrared imaging show that daylength affects short-term recovery after ozone stress in Trifolium subterraneum. Journal of Experimental Botany 60, 3677-3686.

Xiao, Y. N., Li, X. H., George, M. L., Li, M. S., Zhang, S. H., Zheng, Y. L., 2005: Quantitative trait locus analysis of drought tolerance and yield in maize in China. Plant Molecular Biology Reports 23, 155-165.

ZHANG, L. X., LiU, S. X., 2009: Effects of nitrogen and potassium on photosynthetic characteristics in summer maize leaves under long-term water stress. Acta Metallurgica Sinica $15,82-90$.

Zia, S., Sophrer, K., Wenyong, D., Spreer, W., Romano, G., Xiongkui, H., Muller J., 2011: Monitoring physiological responses to water stress in two maize varieties by infrared thermography. International Journal of Agricultural and Biological Engineering $4,7-15$.

Zinselmeier, C., Jeong, B., Boyer, J. S., 1999: Starch and the control of kernel number in maize at low water potentials. Plant Physiology 121, 25-36.

Zlatev, Z., Yordanov, I., 2004: Effects of soil drought on photosynthesis and chlorophyll fluorescence in common bean plants. Bulgarian Journal of Plant Physiology 30, 3-18. 